\title{
Using allogeneic cortical graft preserved in glycerin as spacer in the advancement of tibial tuberosity in 34 dogs $^{1}$
}

\author{
Deusdete C. Gomes Junior², Arianne P. Oriá3 , João Victor R. Vieira ${ }^{3}$, \\ Sirlene F. Barbosa ${ }^{3}$, Alessandra Estrela-Lima ${ }^{3 *}$ and Francisco A. Dórea Neto ${ }^{3}$
}

\begin{abstract}
Gomes Junior D.C., Oriá A.P., Vieira J.V.R., Barbosa S.F., Estrela-Lima A. \& Dórea Neto F.A. 2018. Using allogeneic cortical graft preserved in glycerin as spacer in the advancement of tibial tuberosity in 34 dogs. Pesquisa Veterinária Brasileira 38(12):2246-2253. Escola de Medicina Veterinária e Zootecnia, Universidade Federal da Bahia, Av. Adhemar de Barros 500, Ondina, Salvador, BA 40170-110, Brazil. E-mail: aestrela@ufba.br

Cranial cruciate ligament is the main responsible for knee stability by preventing cranial tibial displacement regarding the femur. Deficiency in this ligament (CCLD) may cause subluxation of the tibia and dysfunction of the pelvic member due to overloading. Tibial osteotomies are among the more current surgical techniques for treating CCLD in dogs and they proportionate the dynamic stability by means of modifying bone geometry and the distribution of forces acting on the articulation. The objective of this work is to describe the use of the allogeneic cortical bone graft conserved in glycerin as a spacer on the tibial tuberosity advancement (TTA) for treating the CCLD. In order to do that, 34 dogs submitted to TTA surgery correction were evaluated, being 23 males (67.35\%) and 11 females (32.35\%). Surgical procedures happened from May 2011 to October 2015. Regarding the surgical procedure after osteotomy of the tibial tuberosity, a disk of allogeneic cortical disk, sawn wedge-hapsed, conserved in glycerin, proportions of $2 \times 1 \mathrm{~mm}$ was applied as spacer, enabling TTA. Advancements from 3 to $12 \mathrm{~mm}$ were executed, depending on the need of the patient. For animals with patella dislocation, trochleoplasty and TTA were executed in order to correct the deviation. The mean \pm SD age of animals was $6.67 \pm 3.58$ and weight was $15.16 \pm 12.97 \mathrm{~kg}$. Mongrel dogs, Poodles and Yorkshire terriers were the most affected ones. From the 36 evaluated knees, $11(30.56 \%)$ were associated with some traumatic process and in $25(69.44 \%)$ there was no relation with previous trauma. From those wounds, 20 (55.56\%) happened in the right limb and 16 (44.44\%) in the left limb and two animals had CCLD bilaterally. Animals had continuous support, discreet drawer movement and negative tibial compression 15 days after surgery. At 30 days, 26 cases (72.22\%) had firm support (FS); at 45 days, 24 cases (66 test at 7 and $67 \%$ ) had FS and eight cases (22.22\%) without claudication (WC). During subsequent radiographic evaluations the progressive incorporation of the graft and osteotomy union were observed. In this study, most of the diagnosed CCLD occurred in males diverging from results obtained by other authors that found greater frequency in females. Support without claudication it was observed in most of the cases of implants at 60 days. We concluded that the conserved allogeneic cortical bone graft was able to promote bone union in TTA of dogs with CCLD. None of the animals had signs of contamination, infection of the surgical wound or rejection related with the presence of the graft, demonstrated by the complete graft-bone incorporation observed early at 45 days in some animals. The glycerin was a good conservation medium for those fragments intended for grafting because, besides being of low cost, it kept bone fragments free of contamination, reducing antigenicity and preserving the
\end{abstract}

\footnotetext{
${ }^{1}$ Received on July 4, 2018.

Accepted for publication on July 17, 2018.

${ }^{2}$ Universidade Federal do Oeste da Bahia, Campus Barra, Av. 23 de Agosto 860, Barra, BA 47100-000, Brazil. E-mail: deusdete.gomes@ufob.edu.br
}

\footnotetext{
${ }^{3}$ Escola de Medicina Veterinária e Zootecnia, Universidade Federal da Bahia (UFBA), Av. Adhemar de Barros 500, Ondina, Salvador, BA 40170-110, Brazil. E-mails: arianneoria@ufba.br, joaovictor12345@hotmail.com, francisco.dorea@ufba.br; *Corresponding author: aestrela@ufba.br
} 
functions of osteoinduction and osteoconduction. The possibility of molding the graft to the animal need is a characteristic favorable to executing the modified technique that could be molded according to the size of the animal, allowing perfect adaptation to the osteotomized local in different breeds. Intercurrences commonly observed in TTA with patellar dislocation, meniscal lesions, tibial crest fracture and displacement were not found in the animals of this study, probably due to the better distribution of forces between the pass screw in TT and the TTA plate confirming that it has good adaptation to the technique conferring to the modified TTA advantages regarding the conventional TTA.

INDEX TERMS: Allogeny, cortical graft, glycerin, tibial tuberosity, dogs, cranial cruciate ligament deficiency, TTA, bone union, osteoinduction, surgery.

RESUMO.- [Uso de enxerto cortical alogênico preservado
em glicerina como espaçador no avanço da tuberosidade tibial em 34 cães.] 0 ligamento cruzado cranial é o principal responsável pela estabilidade do joelho, impedindo o deslocamento da tíbia cranial em relação ao fêmur. A deficiência neste ligamento (CCLD) pode causar subluxação da tíbia e disfunção do membro pélvico devido à sobrecarga. As osteotomias tibiais estão entre as técnicas cirúrgicas mais atuais para o tratamento de CCLD em cães e proporcionam a estabilidade dinâmica por meio da modificação da geometria óssea da distribuição das forças que atuam sobre a articulação. O objetivo desse estudo é descrever o uso do enxerto ósseo cortical alogênico conservado em glicerina como espaçador no avanço da tuberosidade tibial (TTA) para o tratamento do CCLD. Para isso, 34 cães submetidos à cirurgia de TTA foram avaliados, sendo 23 machos $(67,35 \%)$ e 11 fêmeas (32,35\%). Os procedimentos curúrgicos aconteceram entre maio de 2011 e outubro de 2015 . Com relação ao procedimento cirúrgico após a osteotomia da tuberosidade tibial, um disco alogênico cortical, em forma de cunha serrada, conservado em glicerina com proporções de $2 \times 1 \mathrm{~mm}$ foi aplicado como espaçador possibilitando a TTA. Avanços de 3 a $12 \mathrm{~mm}$ foram executados, dependendo da necessidade do paciente. Para animais com luxação da patela, realizou-se a trocleoplastia e a TTA para a correção do desvio. A idade média dos animais foi de $6,67 \pm 3,58$ anos e pesos médios de $15,16 \pm 12,97 \mathrm{~kg}$. Cães sem raça definida, Poodles e Yorkshire Terriers foram os mais afetados. Dos 36 joelhos avaliados, 11 (30,56\%) foram associados a algum processo traumático e em $25(69,44 \%)$ não havia nenhuma relação com um trauma prévio. Dos ferimentos, $20(55,56 \%)$ aconteceram no membro direito e $16(44,44 \%)$ no esquerdo, sendo que dois animais apresentavam CCLD bilateralmente. Os animais tiveram suporte contínuo, discreto movimento de gaveta e compressão tibial negativa 15 dias após a cirurgia. Aos 30 dias, 26 casos tinham suporte firme (FS); aos 45 dias, 24 casos tinham FS e oito casos sem claudicação (WC). Durante avaliações radiográficas subsequentes, observou-se a incorporação progressiva da união do enxerto e da osteotomia. Neste estudo, a maior parte do CCLD diagnosticado ocorreu em machos, divergindo dos resultados obtidos por outros autores que encontraram maior frequência em fêmeas. Suporte sem claudicação foi observado na maioria dos casos de implantes aos 60 dias. Foi concluído que o enxerto ósseo cortical alogênico conservado foi capaz de promover a união óssea na TTA de cães com CCLD. Nenhum dos animais apresentou sinais de contaminação, infecção da ferida cirúrgica ou rejeição relacionada à presença do enxerto, demonstrada pela incorporação completa do enxerto ósseo observada precocemente aos 45 dias em alguns animais. A glicerina foi um bom meio de conservação para os fragmentos destinados à enxertia porque, além do menor custo, manteve os fragmentos ósseos livres de contaminação, reduzindo a antigenicidade e preservando as funções de osteoindução e osteocondução. A possibilidade de moldagem do enxerto à necessidade do animal é uma característica favorável à execução da técnica modificada que pode ser moldada de acordo com o tamanho do animal, possibilitando perfeita adaptação ao local osteotomizado em diferentes raças. Intercorrências comumente observadas na TTA com luxação patelar, lesões meniscais, fratura da crista tibial e deslocamento não foram encontradas nos animais deste estudo, provavelmente devido à melhor distribuição de forças entre a passagem do parafuso no TT e a placa do TTA, confirmando que tem boa adaptação à técnica conferindo às vantagens da TTA modificada em relação à TTA convencional.

TERMOS DE INDEXAÇÃO: Enxerto cortical, alogenia, glicerina, tuberosidade tibial, caninos, ligamento cruzado cranial, ATT, união óssea, osteoindução, cirurgia.

\section{INTRODUCTION}

Deficiency of the cranial cruciate ligament (CCLD) is associated to a previous trauma or ligament degeneration, causing subluxation of the tibia and dysfunction of the pelvic member due to overloading. Due to the frequent demand of surgeries for correction CCLD, several techniques were elaborated, modified and adapted with the objective of improving results and reducing costs (Silva 2012, Castilho et al. 2014).

In tibial tuberosity advancement (TTA) procedures, the use of titanium cages are necessary for the maintenance and filling of the space created by osteotomy and TTA. Such implants are made in pre-determined sizes of 3,6, 9 and $12 \mathrm{~mm}$, and with a wide variety of lengths. This method has been used with good results; however, complications such as infection, tibial tuberosity fracture and meniscal lesions are observed (Costa et al. 2017, Dyall \& Schmokel 2017).

Several studies have used materials alternative to the titanium cage to provide biocompatible implants that would be absorbed and replaced by the host bone. Among these, Silva (2012) used hydroxyapatite and polycaprolactan, observing bone integration after six months of evaluation. Von Lande et al. (2012) compared radiographic scarring in 48 dogs using bovine xenograft and in 34 dogs as a spongy autogenous bone graft to fill the gap resulting from TTA. Similarly, Marques et al. (2017) evaluated the time for bone consolidation with spongy grafts in titanium cages. Medeiros 
(2011) used castor bean polymer spacers in clinical cases. Castilho et al. (2014) fabricated calcium phosphate cement spacers by 3D prototyping for the treatment of cranial cruciate ligament rupture (CCLR) in dogs and concluded that the design, fabrication and application of the proposed implant was successful.

The use of bone grafts is a relevant and well established procedure in both human and veterinary orthopedic surgery. Traditionally, large bone defects are filled with autogenous bone grafts for faster bone formation, or with preserved allogenic graft segments for greater biomechanical resistance. The allogeneic cortical graft have interesting characteristics as high biological value, providing temporary mechanical structure, serving as a framework for new bone growth (osteoconduction) while maintaining the ability to induce osteogenesis (osteoinduction), besides being absorbed and slowly replaced by the host's own tissue (Ragetly \& Griffon 2011).

Conserved cortical grafts are easy to acquire, maintain and are indicated for the filling of major defects, which makes it possible to use them as spacers in TTA. For that it is necessary to modify the main TTA technique for graft fixation and osteotomy stabilization.

The objective of this work was to evaluate and follow up animals that used both the dog allogenic bone graft, glycerin-preserved, as a spacer in replacement of the titanium cages in TTA surgeries, and the modification of the conventional technique.

\section{MATERIALS AND METHODS}

Thirty-four dogs submitted to TTA surgery for CCLD correction were evaluated, using bone graft of dog conserved in glycerol at $98 \%$ as spacer. Surgical procedures happened from May 2011 to October 2015 , in two veterinary hospitals.

As an inclusion criterion, animals should have, besides history compatible with CCLD, positive drawer and tibial compression tests. Results will be descriptively presented by percentage and mean.

After physical test, radiographic preoperative evaluations of affected knees on mid-lateral and cranial-caudal projections were performed in order to measure TTA and to evaluate the degree of joint degeneration. X-rays of the tibia in medial-lateral projection for calculating the angle of the tibial plateau were executed according to methodology established by other author (Slocum \& Devine 1983).

For surgical procedure, animals were intramuscularly pre-medicated with morphine sulfate (Dimorf ${ }^{\circledR} 1 \%, 0.5 \mathrm{mg} / \mathrm{kg}$, Cristália, São Paulo, Brazil), acepromazine hydrochloride (Acepram ${ }^{\circledR} 0.2 \%, 0.02-0.05 \mathrm{mg} / \mathrm{kg}$, Vetnil, São Paulo, Brazil) or chlorpromazine hydrochloride (Longactil ${ }^{\circledR}$ $0.5 \%, 0.5 \mathrm{mg} / \mathrm{kg}$, Cristália, São Paulo, Brazil) depending on the results from clinical evaluation.

After lumbosacral and affected pelvic limb trichotomies the anesthetic induction was executed, intravenously, using propofol (Propovan $^{\circledR}$ 1\%,5mg/kg - dose dependent, Cristália, São Paulo, Brazil). Maintenance with isoflurane (Vetflurano ${ }^{\circledR}$, Virbac, São Paulo, Brazil)was executed in oxygen at $100 \%$, in semi-closed system. For epidural anesthesia, lidocaine hydrochloride with vasoconstrictor (Xylestesin ${ }^{\circledR} \%, 0.25 \mathrm{mg} / \mathrm{kg}$, Syntec, São Paulo, Brazil) was used. Additionally were also used, by intravenous route, cephalothin (Cefalotina Sódica ${ }^{\circledR} 20 \%, 30 \mathrm{mg} / \mathrm{kg}$, Eli Lilly, Pernambuco, Brazil)and meloxicam (Maxicam ${ }^{\circledR} 2 \%, 0.2 \mathrm{mg} / \mathrm{kg}$, Ouro Fino, São Paulo, Brazil)

For TTA execution, joints were medially addressed according to the routine technique (Piermattei et al. 2006). Medial meniscectomies were performed in all knees and the fragments from the ruptured cranial cruciate ligament were removed. Animals having patella dislocation were submitted to chondroplasia for deepening the trochlear groove (Fig.1A). Knees were irrigated with physiological solution, patella was repositioned and the joint capsule sutured with Wolf's point or simply interrupted with polyamide thread. The prolongation in the distal direction was extended in order to approach the tibial tuberosity (TT) and the proximal medial face of the tibia. Then, the length and width of TT were measured, determining the positioning of the osteotomy (Fig.1B). Osteotomy was performed with the help of oscillating saw and TT was advanced with help of a lever.

For TTA a disk of varied dimensions was used, depending on the patient's need (3-12mm of diameter), wedge shaped sawed, measuring in proportion of $2 \times 1 \mathrm{~mm}$ of metacarpal or dog ulna preserved in glycerin (Fig.1C). The graft was hydrated with physiological solution, applied at the osteotomy place and fixed with titanium or stainless steel bolt $(1.5,2.0,2.7$ or $3.5 \mathrm{~mm})$ trespassing the TT toward the tibia (Fig.1D). In animals having medial patellar dislocation, TT was transposed laterally (Fig.1E). Immediately thereafter, a titanium plate for TTA (Cão Médica Comércio de Materiais Cirúrgicos Veterinários Ltda, São Paulo, Brazil) was molded and applied on the medial surface of the tibia with the help of titanium or stainless steel bolts (Fig.1F).

Immediately thereafter, the plate and the osteotomy were recovered by the union of adjacent tissues with stitches in Sultan using polyamide yarn (Nylon ${ }^{\circledR}, 3-0$ a 0 , Shalon, Goiás, Brazil), followed by subcutaneous suture with simple continuous standard using polyglactin yarn (Vicryl ${ }^{\circledR}, 3-0$ a 0 , Ethicon, São Paulo, Brazil) and dermorrhaphy with simples stitches using polyamide yarn.

During post operative amoxicillin with potassium clavulanate $20 \mathrm{mg} / \mathrm{kg} / \mathrm{VO} / \mathrm{BID}$ (Agemoxi CL ${ }^{\circledR}$, Agener União, São Paulo, Brazil) or cephalexin $30 \mathrm{mg} / \mathrm{kg} / \mathrm{VO} / \mathrm{BID}$ (Rilexine ${ }^{\circledR}$, Virbac, São Paulo, Brazil) were prescribed during 10 days; meloxicam $0.1 \mathrm{mg} / \mathrm{kg} / \mathrm{VO} / \mathrm{SID}$ (Meloxivet ${ }^{\circledR}$, Duprat, Rio de Janeiro, Brazil) during five days; dipyrone $25 \mathrm{mg} / \mathrm{kg} / \mathrm{VO} / \mathrm{TID}$ (Generic drug) during 7 days and tramadol hydrochloride $3 \mathrm{mg} / \mathrm{kg} / \mathrm{VO} / \mathrm{TID}$ (Cronidor ${ }^{\circledR}$, Agener União, São Paulo, Brazil) during 5 days. Space restriction and exercise limitation were recommended during the first weeks of post-operative. All animals remained with splint during the first 15 days.

Clinical and radiographic evaluations were performed postoperatively between the 7 th and the 10 th day, when stitches were removed, and repeated at 15, 30, 45 and 60 days of surgery. During clinical evaluations were observed the degree of claudication, return to function and limb support, being classified in: without support (WS), when the animal had no support from limb; continuous support (CS), when the animal had support from the limb, however it had difficulties walking; firm support (FS), when the animal had support from the without major difficulties during gait; and no claudication (WC), when it had no degree of claudication. During radiographic evaluations were observed the positioning of implants, graft fusion and the retraction of the space between tibia and TT.

\section{RESULTS}

Individual information can be seen in Table 1. A total of 36 knees in 34 dogs were evaluated, being 23 males (67.35\%) and 11 females (32.35\%), their ages between six and 10 years old and five of them (14.71\%), between 11 and 14 years old. The mean \pm SD of animals ages was $6.67 \pm 3.58$ years and of weight $15.16 \pm 12.97 \mathrm{~kg}$.

From dogs included in the study were found: one $(2.94 \%)$ representatives of breeds Lhasa Apso, Maltese, Pit-Bull, Golden 

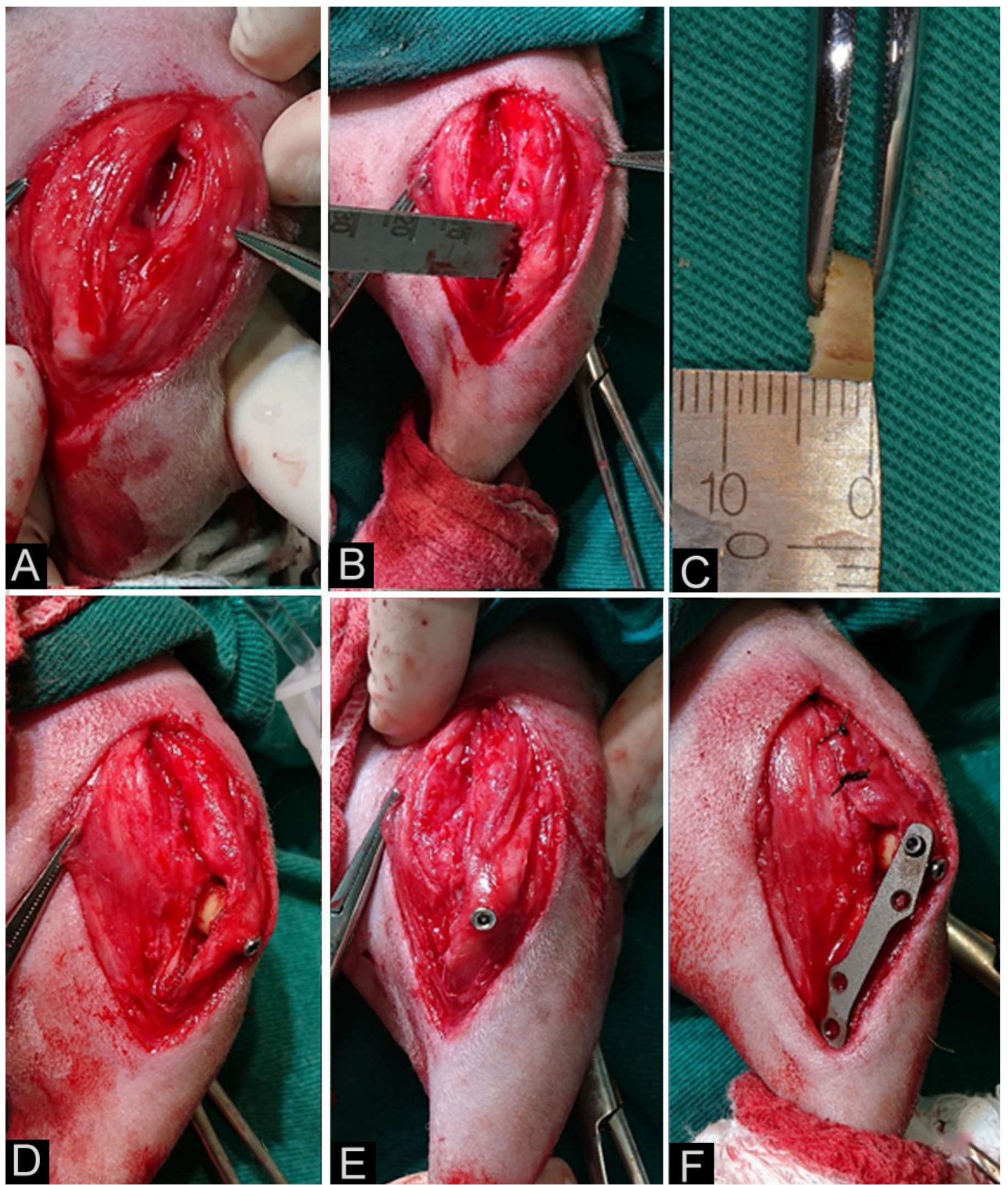

Fig.1. Images of tibial tuberosity advancement (TTA) using bone graft. (A) Deepening of the trochlear groove, (B) tibial tuberosity (TT) osteotomy with the help of oscillating saw, (C) preparation of the wedge shaped sawed graft, (D) application of graft and fixation of bolt trespassing TT, (E) cranial aspect of the bolt applied on TT, (F) application of TTA plate on the medial surface of the tibia. 
Table 1. Animals submitted to tibial tuberosity advancement (TTA), cranial cruciate ligament (CCLD) traumatic or not and clinical presentation time

\begin{tabular}{|c|c|c|c|c|c|c|c|c|}
\hline Case no. & Sex & Breed & $\begin{array}{c}\text { Age } \\
\text { (years) }\end{array}$ & Weight (Kg) & PL & $\begin{array}{c}\text { Knee } \\
\text { Affected }\end{array}$ & Cause & $\mathrm{TL}$ \\
\hline 1 & $\mathrm{~F}$ & Mixed & 13 & 6.0 & $\mathrm{~N}$ & Right & $\mathrm{T}$ & 01 \\
\hline 2 & M & Poodle & 6 & 6.3 & $\mathrm{Y}$ & Right & NT & 01 \\
\hline 3 & M & Poodle & 7 & 5.4 & $\mathrm{Y}$ & Right & NT & 04 \\
\hline 4 & M & Mixed & 4 & 16.9 & $\mathrm{~N}$ & Right & NT & 02 \\
\hline 5 & M & $\begin{array}{l}\text { English } \\
\text { Bulldog }\end{array}$ & 2 & 23.5 & $\mathrm{~N}$ & Left & NT & 02 \\
\hline 6 & M & Poodle & 11 & 10.3 & $\mathrm{Y}$ & Left & $\mathrm{T}$ & 01 \\
\hline 7 & M & $\begin{array}{l}\text { Labrador } \\
\text { Retriever }\end{array}$ & 9 & 46.8 & $\mathrm{~N}$ & Left & NT & 01 \\
\hline 8 & $\mathrm{~F}$ & Poodle & 6 & 5.3 & Y & Right & NT & 01 \\
\hline 9 & M & Pitbull & 2 & 37.5 & $\mathrm{~N}$ & Left & NT & 03 \\
\hline 10 & M & $\begin{array}{c}\text { Brazilian } \\
\text { Mastiff }\end{array}$ & 8 & 51.0 & $\mathrm{~N}$ & Right & NT & 01 \\
\hline 11 & M & $\begin{array}{c}\text { Yorkshire } \\
\text { Terrier }\end{array}$ & 2 & 4.5 & $\mathrm{Y}$ & Right & $\mathrm{T}$ & 01 \\
\hline 12 & $\mathrm{~F}$ & $\begin{array}{l}\text { Golden } \\
\text { Retrievier }\end{array}$ & 4 & 30.9 & $\mathrm{~N}$ & Left & NT & 01 \\
\hline 13 & $\mathrm{~F}$ & Pinscher & 8 & 6.5 & $\mathrm{Y}$ & Left & NT & 01 \\
\hline 14 & $\mathrm{~F}$ & $\begin{array}{c}\text { Brazilian } \\
\text { Mastiff }\end{array}$ & 6 & 39.2 & $\mathrm{~N}$ & Right & NT & 04 \\
\hline 15 & M & Mixed & 4 & 16.5 & $\mathrm{~N}$ & Right & NT & 03 \\
\hline 16 & $\mathrm{~F}$ & $\begin{array}{l}\text { English } \\
\text { Bulldog }\end{array}$ & 3 & 23.5 & $\mathrm{~N}$ & Left & NT & 01 \\
\hline 17 & M & Mixed & 5 & 29.0 & $\mathrm{~N}$ & Right & NT & 01 \\
\hline $18^{*}$ & $\mathrm{~F}$ & Poodle & 9 & 5.5 & $\mathrm{Y}$ & Left & NT & 02 \\
\hline $18^{*}$ & $\mathrm{~F}$ & Poodle & 9 & 5.5 & $\mathrm{Y}$ & Right & NT & 03 \\
\hline 19 & M & Lhasa Apso & 5 & 6.2 & $\mathrm{Y}$ & Right & $\mathrm{T}$ & 05 \\
\hline 20 & M & $\begin{array}{l}\text { Yorkshire } \\
\text { Terrier }\end{array}$ & 3 & 3.4 & $\mathrm{~N}$ & Right & NT & 09 \\
\hline 21 & $\mathrm{~F}$ & $\begin{array}{l}\text { Yorkshire } \\
\text { Terrier }\end{array}$ & 10 & 4.2 & $\mathrm{Y}$ & Left & NT & 04 \\
\hline 22 & M & Mixed & 10 & 29.7 & $\mathrm{~N}$ & Left & NT & 07 \\
\hline 23 & M & Pinscher & 8 & 8.1 & Y & Left & NT & 03 \\
\hline 24 & M & Mixed & 8 & 8.3 & $\mathrm{Y}$ & Left & NT & 17 \\
\hline 25 & $\mathrm{~F}$ & $\begin{array}{l}\text { Yorkshire } \\
\text { Terrier }\end{array}$ & 5 & 5.8 & Y & Right & NT & 08 \\
\hline $26^{*}$ & $\mathrm{~F}$ & Mixed & 2 & 19.3 & $\mathrm{~N}$ & Left & $\mathrm{T}$ & 03 \\
\hline $26^{*}$ & $\mathrm{~F}$ & Mixed & 2 & 19.3 & $\mathrm{~N}$ & Right & $\mathrm{T}$ & 02 \\
\hline 27 & M & Poodle & 7 & 14.7 & $\mathrm{~N}$ & Left & $\mathrm{T}$ & 01 \\
\hline 28 & M & $\begin{array}{l}\text { Yorkshire } \\
\text { Terrier }\end{array}$ & 3 & 5.8 & Y & Left & $\mathrm{T}$ & 01 \\
\hline 29 & M & Mixed & 13 & 10.3 & $\mathrm{~N}$ & Right & NT & 04 \\
\hline 30 & M & Mixed & 9 & 9.1 & $\mathrm{~N}$ & Right & $\mathrm{T}$ & 04 \\
\hline 31 & $\mathrm{~F}$ & $\begin{array}{l}\text { Yorkshire } \\
\text { Terrier }\end{array}$ & 13 & 4.7 & $\mathrm{Y}$ & Left & NT & 02 \\
\hline 32 & M & Mixed & 14 & 14.7 & Y & Right & $\mathrm{T}$ & 03 \\
\hline 33 & M & Poodle & 5 & 4.6 & Y & Right & NT & 04 \\
\hline 34 & M & Maltese & 5 & 7.7 & $\mathrm{Y}$ & Right & $\mathrm{T}$ & 02 \\
\hline
\end{tabular}

Retriever, and Labrador Retriever, two (5.88\%) representatives of breeds Brazilian Mastiff, English Bulldog and Pinscher. Mixed dogs were the most affected ones (10 animals, 29.41\%) followed by Poodles (seven animals, 20.59\%) and Yorkshires (six animals, 17.65\%).
Regarding the weight, it ranged from 3.4 until $51 \mathrm{~kg}$, from those, 11 animals (35.33\%) in the range between 3.4 and $6 \mathrm{~kg}$, seven animals $(20.57 \%)$ between 6.2 and $9.1 \mathrm{~kg}$, nine animals (26.45\%) between 10.3 and $23.5 \mathrm{~kg}$ and six animals (17.65\%) between 29 and $51 \mathrm{~kg}$. 
From the 36 evaluated knees, 11 (30.56\%) were associated with some traumatic process and in $25(69.44 \%)$ there was no relation with previous trauma. From those wounds, $20(55.56 \%)$ happened in the right limb and $16(44.44 \%)$ in the left limb, from those previously mentioned, two animals had CCLD bilaterally, represented by Cases 18 and 26. Time between lesion occurrences until clinical conduction ranged between one and 17 weeks. In most of the cases, 31 (86.11\%) of them, this period did not exceed four weeks. In animals of breeds Poodle, Yorkshire, Pinscher and Maltese, 18 knees $(50 \%)$ had patella luxation at clinical evaluation.

During the 15 initial days, animals were kept with splint and had CS of limbs. After 30 days of the surgical procedure, from the 36 operated knees, $26(72.22 \%)$ had FS, three $(8.33 \%)$ CS (Cases 29, 30 and 33), five (13.89\%) WS (Cases 3, 5, 10, 18 and 31) and two (5.56\%) WC (Cases 19 and 34). At 45 days, 24 $(66.67 \%)$ had FS, 1 (2.78\%) CS (Case 33), three (8.33\%) WS (Cases 3, 5, 10 and 17) and eight (22.22\%) WC. At 60 days two knees (5.56\%) had FS (Cases 10 and 28), two (5.56\%) WS (Cases 3 and 33 ) and 33 (88.89\%) WC.

Cases 2, 3, 4, 5, 6, 17, 28 and 33 had plates removed due to exposition of implants, loose implants or patient discomfort. In Case 3 trauma was reported at 90 days with exposition of implants. Those were removed, obtaining FS after one week and WC after 40 days of the removal of implants. In Case 28, a surgical intervention was performed for removal of plate at 45 days.

In Case 33, at 15 days of postoperative, after removal of splint, a small exposition of the plate in the portion inserted on the tibial tuberosity was observed. A dermorrhaphy was performed with polyamide yarn 3.0 with simple interrupted stitches that were removed after 10 days. The same patient remained with CS during the whole evaluating period and, still, there was marked instability. At 90 days, another procedure was performed to removal of grafts and stabilization using the technique of fabelo-tibial suture.
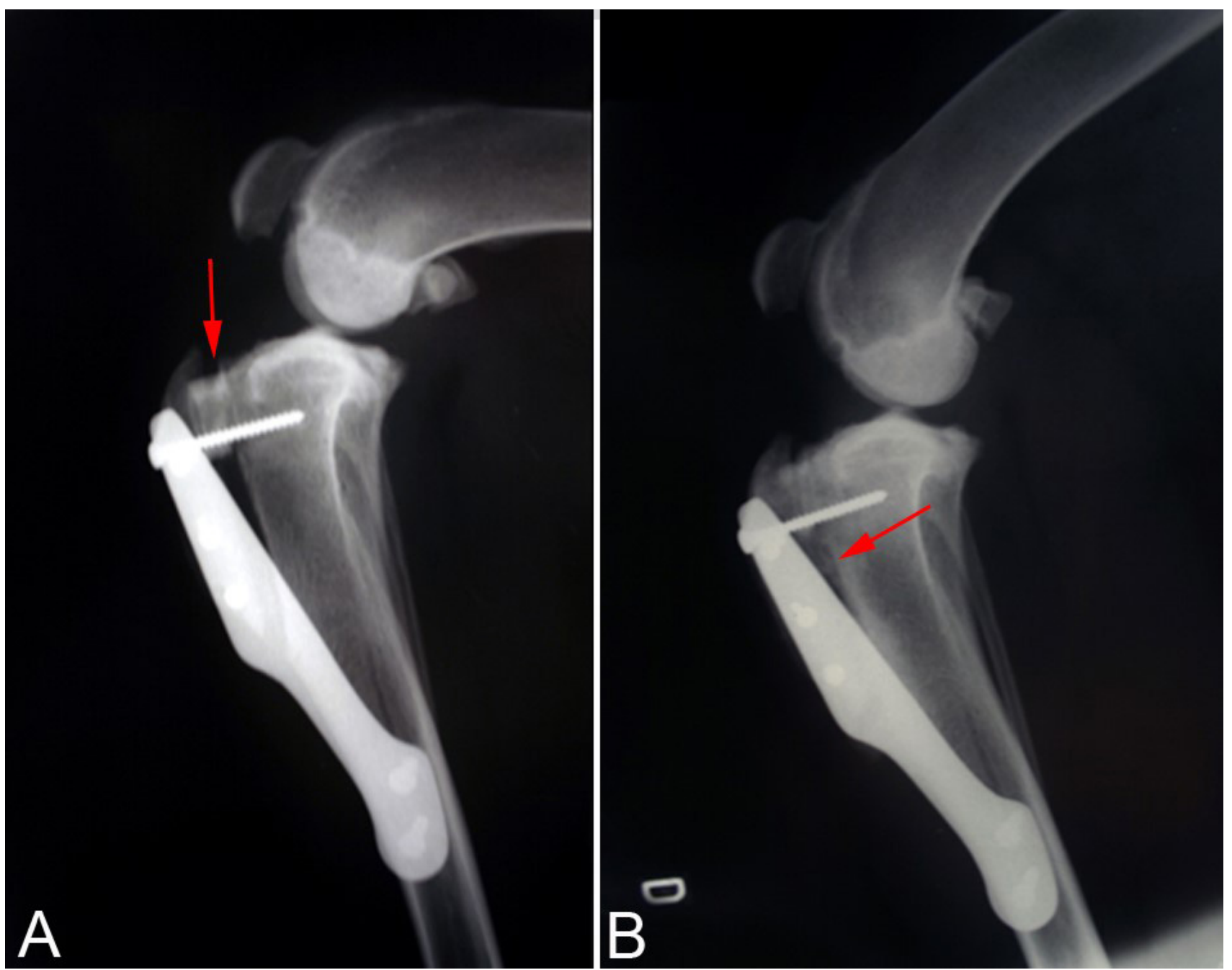

Fig.2. Radiographic images of the stifle joint of a dog at (A) 30 and (B) 60 days after tibial tuberosity advancement (TTA) procedure. (A) Evident margins of the bone graft between the tuberosity of the tibia and the body of the tibia and discrete bone proliferation on the proximal surface of both (arrow). (B) Less evident graft margins and identification of periosteal proliferation near the cranial surface of the tibia filling the space between the plaque, the graft and the tibia, without signs of infectious process or rejection, indicating an adequate process of bone consolidation (arrow). 
No late evaluations of the other cases were possible, however, it was reported by phone contact that the animals marched without alterations.

Regarding radiographic evaluations, at 30 days was evidenced the beginning of the process of graft incorporation with the production of new bone on the interfaces between TT, tibia and graft. After 45 and 60 days it was noticed the filling of the gap over the graft, enabling reduction of graft density, incorporation and remodeling of the new bone, distal union of crest towards the graft and, in some cases, indication of total closure of the advanced space (Fig.2).

\section{DISCUSSION}

Characterizing the population of the dogs of this study, it is possible to perceive that most of the diagnosed CCLD occurred in males (67.35\%), diverging from results obtained by (Bach et al. 2015) that found greater frequency in females (68.75\%). Predominance was observed in wounds in Mixed dogs $(29.41 \%)$, followed by breeds Poodle and Yorkshire Terrier (38.24\%), suggesting that such discovery is due to concomitant dislocations of the patella and overweight as already described by other authors (Duval et al. 1999, Guerrero et al. 2007, Drygas et al. 2010).

In most of the cases of implants (88.89\%) at 60 days, it was observed support without claudication. The animal represented by Case 33 kept claudication in continuous support at the end of the 60 days of follow-up, that can be associated to loose implants or positioning of the crest bold that, when positioned over the patellar ligament may generate claudication. It cannot be excluded the possibility of individual sensibility of the animal, not reacting well to the technique. However, due to excessive instability in this knee it was necessary to use the additional technique of fabelo-tibial suture, most probably due to the partial wound on the caudal cruciate ligament or on the medial collateral that was not perceived during the initial surgical act.

Patella dislocations were no hindrance for performing TTA with bone graft, on the contrary, the possibility of transposing TT and the application of the bolt pierced by TT, the graft and the tibia, facilitated the reorganization and alignment of the muscular apparatus of the quadriceps without increasing operative time (Duval et al. 1999, Guerrero et al. 2007, Drygas et al. 2010).

Glycerin was a good conservation medium for those fragments intended for grafting because, besides being of low cost, it kept bone fragments free of contamination, reducing antigenicity and preserving the functions of osteoinduction and osteoconduction, as described by other authors (Cavassani et al. 2001, Ziliotto et al. 2003). Furthermore, none of the animals had signs of contamination, infection of the surgical wound or rejection related with the presence of the graft, demonstrated by the complete graft-bone incorporation observed early at 45 days in some animals.

During radiographic evaluations of the 30 days, it is possible to see the beginning of the graft incorporation into the bone tissue and, in subsequent evaluations, it is possible to verify absorption and remodeling of the graft, besides retraction of the tibia advancement gap. Similarly, other author (Silva 2012) when using the hydroxyapatite block evidenced, at 30 days of postoperative, fast bone consolidation of the tibial tuberosity and bone formation over the ceramics in proximal region. However, it is known that calcium phosphate ceramics with hydroxyapatite are very slowly absorbed, causing a very time-consuming process of remodeling.

Compared to what happened in TTA with bone graft in this study, in the surgeries of member preservation in which it was also used allogeneic cortical bone graft conserved in glycerin at $98 \%$, it was found that in 30 days there was onset of graft resorption and bone bridges formation, that became more evident at 90 days. In 120 days the graft resorption was almost complete, having formation of bone callus and bone remodelation without perception of clinical, radiographic or histopathological signs of implant rejection (Ziliotto et al. 2003).

Cages used in TTA had sizes of 6,9 and $12 \mathrm{~mm}$ of width (Hoffmann et al. 2006), bringing a limitation to the technique to fit perfectly in different sizes of dogs. The possibility of molding the graft to the animal need is a characteristic favorable to executing the modified technique, corroborating results of the castor polymers (Ricinus communis) in the making of the spacer for the TTA technique who observed that it was a biocompatible material that could be molded according to the size of the animal, allowing perfect adaptation to the osteotomized local in different breeds (Medeiros 2011).

Using the technique of TTA modified with bioceramic spacer, constituted of brushite, tricalcium phosphate and monetite, 3D printed, of porous morphology and highly permeable was observed that the material used had good acceptance without presenting adverse reactions, promoting the recovery of the motor function. X-rays showed that there were signs of graft reabsorption and bone remodeling around it, with significant union of osteotomized interfaces, demonstrating that the graft promoted better biocompatibility and osteoconductivity when compared with the standard titanium cage, used in the conventional TTA technique (Castilho et al. 2014).

The main postoperative complications observed in TTA on the medium and long term are: Patellar dislocation, meniscal lesions, tibial crest fracture and displacement (Hoffmann et al. 2006, Kim et al. 2008). Tibial crest fracture may be attributed to fails during osteotomy and improper positioning of the plate or of the cage (Nutt et al. 2015). Intercurrences commonly observed in TTA such as patellar dislocation, meniscal injury, tibial tuberosity fracture and infection (Costa et al. 2017, Dyall \& Schmokel 2017) were not observed in the animals of this study, probably due to the better distribution of forces between the pass screw in TT and the TTA plate. Another reason could be attributed to the plate being fixed with bolts in TT and not with a clip as in the original technique.

No intercurrences that could be attributed to the graft were observed, corroborating that it has good adaptation to the technique conferring to the modified TTA advantages regarding the conventional TTA.

\section{CONCLUSION}

The preserved allogeneic cortical graft was able to promote adequate advancement of tibial tuberosity (TT) and bone union in all cases and proved to be feasible to be used in this kind of procedure in the absence of titanium cages.

Acknowledgements.- The authors would like to thank to Coordination for the Improvement of Higher Education Personnel (CAPES) for the scholarship provided by National Postdoctoral Program. 
Conflict of interest statement.- The authors report no conflicts of interest. The authors alone are responsible for the content and writing of paper.

\section{REFERENCES}

Bach M., Villanova Junior J.A., Tasqueti U.I., Pimpão C.T., Prado A.M.B. \& Michellotto Junior P.V. 2015. Estudo retrospectivo de cães portadores de ruptura do ligamento cruzado cranial: 32 casos (2006 a 2012). Semina, Ciênc. Agrárias 36(3):1409-1418.

Castilho M., Dias M., Vorndran E., Gbureck U., Fernandes P., Pires I., Gouveia B., Armés H., Pires E. \& Rodrigues J. 2014. Application of a 3D printed customized implant for canine cruciate ligament treatment by tibial tuberosity advancement. Biofabrication 6(2):1-13. <http://dx.doi. org/10.1088/1758-5082/6/2/025005> <PMid:24658159>

Cavassani M.M., Moraes J.R.E. \& Padilha Filho J.G. 2001. Função osteoindutora de fragmentos ósseos conservados em glicerina a 98\%: estudo experimental em ratos. Ciência Rural 31(3):445-448. <http://dx.doi.org/10.1590/ S0103-84782001000300013>

Costa M., Craig D., Cambridge T., Sebestyen P., Su Y. \& Fahie M.A. 2017. Major complications of tibial tuberosity advancement in 1613 dogs. Vet. Surg. 46(4):494-500. <http://dx.doi.org/10.1111/vsu.12649><PMid:28370168>

Dyall B. \& Schmokel H. 2017. Tibial tuberosity advancement in small-breed dogs using TTA rapid implants: complications and outcome. J. Small Anim. Pract. 58(6):314-322. <http://dx.doi.org/10.1111/jsap.12654> <PMid:28247999>

Drygas K.A., Pozzi A., Goring R.L., Horodyski M. \& Lewis D.D. 2010. Effect of tibial plateau leveling osteotomy on patellar tendon angle: a radiographic cadaveric study. Vet. Surg. 39(4):418-424. <http://dx.doi.org/10.1111/ j.1532-950X.2010.00665.X><PMid:20345525>

Duval J.M., Budsberg S.C., Flo G.L. \& Sammarco J.L. 1999. Breed, sex, and body weight as risk factors for rupture of the cranial cruciate ligament in young dogs. J. Am. Vet. Med. Assoc. 215(6):811-814. <PMid:10496133>

Guerrero T.G., Geyer H., Hässig M. \& Montavon P.M. 2007. Effect of conformation of the distal portion of the femur and proximal portion of the tibia on the pathogenesis of cranial cruciate ligament disease in dogs. Am. J. Vet. Res. 68(12):1332-1337. <http://dx.doi.org/10.2460/ajvr.68.12.1332> <PMid:18052737>

Hoffmann D.E., Miller J.M., Ober C.P., Lanz O.I., Martin R.A. \& Shires P.K. 2006. Tibial tuberosity advancement in 65 canine stifles. Vet. Comp. Orthop.
Traumatol.19(4):219-227.<http://dx.doi.org/10.1055/s-0038-1633004> <PMid:17143394>

Kim S.E., Pozzi A., Kowaleski M.P. \& Lewis D.D. 2008. Tibial osteotomies for cranial cruciate ligament insufficiency in dogs. Vet. Surg. 37(2):111-125. <http://dx.doi.org/10.1111/j.1532-950X.2007.00361.x><PMid:18251804>

Marques D.R.C., Ibañez J.F., Monteiro J.F., Hespanha A.C.V., Eggert M., Becker A. \& Freita I.B. 2017. The effect of cancellous bone grafts on time to consolidation at osteotomy site following tibial tuberosity advancement in dogs. Semina, Ciênc. Agrárias 38(3):1417-1426.

Medeiros R.M. 2011. Desenvolvimento, aplicação e avaliação de nova técnica de avanço da tuberosidade tibial com uso de espaçador de polímero de mamona fixado com parafusos para correção da ruptura do ligamento cruzado cranial em cães. Dissertação de Mestrado, Universidade Estadual Paulista "Júlio de Mesquita Filho", Jaboticabal. 58p.

Nutt A.E., Garcia-Fernandez P., San Roman F., Parkin T. \& Calvo I. 2015. Risk factors for tibial tuberosity fracture after tibial tuberosity advancement in dogs. Vet. Comp. Orthop. Traumatol. 28(2):116-123. <http://dx.doi. org/10.3415/VCOT-14-02-0022><PMid:25650590>

Piermattei D.L., Flo G.L. \& DeCamp C.E. 2006. Fractures of the femur and patella, p.512-561. In: Ibid. (Eds), Brinker, Piermattei, and Flo's Handbook of Small Animal Orthopedics and Fracture Repair. 4th ed. W.B. Saunders, St Louis.

Ragetly G.R. \& Griffon D.J. 2011. The rationale behind novel bone grafting techniques in small animals. Vet. Comp. Orthop. Traumatol. 24(1):1-8. <http://dx.doi.org/10.3415/VCOT-10-03-0040> <PMid:20830454>

Silva W.G. 2012. Biomaterial como implante ortopédico no avanço da tuberosidade tibial em cães. Dissertação de Mestrado, Universidade Federal de Lavras, Lavras. 78p.

Slocum B. \& Devine T. 1983. Cranial tibial thrust: a primary force in the canine stifle. J. Am. Vet. Med. Assoc. 183(4):456-459. <PMid:6618973>

Von Lande R.G., Worth A.J., Guerrero T.G., Owen M.C. \& Hartman A. 2012. Comparison between a novel bovine xenoimplant and autogenous cancellous bone graft in tibial tuberosity advancement. Vet. Surg. 41(5):559-567. <http://dx.doi.org/10.1111/j.1532-950X.2012.01003.x><PMid:22632456>

Ziliotto L., Daleck C.R., Padilha Filho J.G., Souza A.P., Fantinatti A.P. \& Diniz P.P.V.P. 2003. Utilização de implante ósseo cortical alógeno conservado em glicerina para preservação de membro torácico: estudo experimental em cães. Acta Cir. Bras. 18(2):107-115. <http://dx.doi.org/10.1590/S010286502003000200007> 